Цитування на цю статтю:

Нестеренко НА, Крюковська ОС. Аналіз системи тренувального процесу спортсменок 3 пляжного волейболу в річному макроциклі на етапі спеціалізованої базової підготовки. Вісник Прикарпатського університету. Серія: Фізична культура. 2020 Листоп 24; 36: 48-53

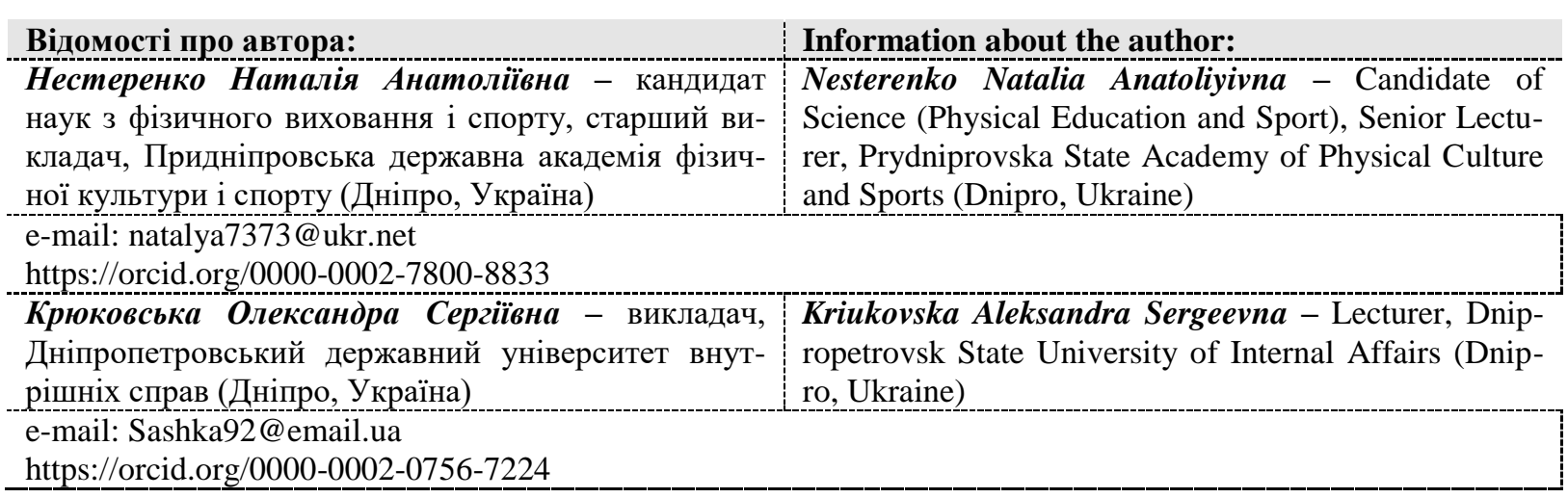

УДК 615.838+616-036.82+616.24

Роман Сарапук doi: 10.15330/fcult.36.53-57

\title{
ЕФЕКТИВНІСТЬ ЗАСТОСУВАННЯ ПЛАВАННЯ ДЛЯ ВІДНОВЛЕННЯ ФУНКЦІОНАЛЬНОГО СТАНУ КАРДІОРЕСПІРАТОРНОЇ СИСТЕМИ ПІСЛЯ ПЕРЕНЕСЕНИХ ЗАПАЛЕНЬ ЛЕГЕНЬ
}

\begin{abstract}
Мета. Встановити вплив занять плаванням на відновлення функціональних резервів кардіореспіраторної системи після перенесених запальних захворювань легень. Методи. У дослідженні взяли

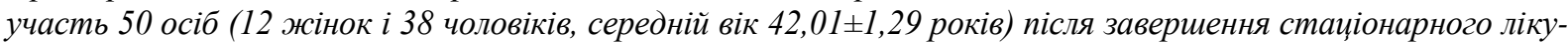
вання з приводу запальних захворювань легень в пульмонологічному відділенні Івано-Франківського обласного фтизіопульмонологічного иентру. 3 а погодженням з лікуючими лікарями вони були скеровані у санаторії “Алмаз” $i$ “Кристал (м. Трускавецьь) де основним групам (ОГ) у кількості 25 осіб чоловічої $і 6$ жіночої статі було створено умови для щзоденних занять плаванням протягом 18 днів. Тривалість кожного заняття складала 45 хвилин, а обсяг фізичного навантаження - 400-800 м при ЧСС 120-140 уд/хв. Контрольні групи протягом перебування в санаторії плавання не використовували. Для оцінки основних показників функиії зовнішнього дихання використовувався комп'ютерний спірометр Microspiro HI-501. Визначення загальної фізичної прачездатності здійснювали за допомогою проби Джеймса. Обстеження здійснювали двічі (до початку і після завершення циклу занять плаванням). Результати. Порівняльний аналіз змін середніх значень дихального об'єму і життєвої ємності легень контрольної й основної групи чоловіків свідчить про те, щуо в основній групі иі показники зовнішнього дихання перевищують дані групи контролю на 10,9\% і 4,0\% відповідно (p<0,05). Аналіз засвідчує, Щодо жінок, то величини дихального об'єму та життєвої ємності легень основної групи наприкінці занять зросли у порівнянні з групою контролю на 5,0\% і 12,4\% відповідно. Вірогідні зміни виявлені також і в показниках хвилинного об' $є м у$ дихання, форсованого об'єму дихання та пікової швидкості видиху як у чоловіків, так $і$ в жінок. Висновок. Застосування плавання у відновному періоді осіб, які перенесли запальні захворювання дихальної системи забезпечує нормалізацію функціонування як дихальної, так і серцево-судинної системи, щзо опосередковано свідчить про нормалізачію механізмів нейрогуморальної регуляиії функцій організму.
\end{abstract}

Ключові слова: плавання, запальні захворювання легень, функиіональний стан.

Aim. To establish the influence of swimming on the restoration of functional reserves of the cardiorespiratory system after inflammatory lung diseases. Methods. The study involved 50 people (12 women and 38 men, mean age $42.01 \pm 1.29$ years) after inpatient treatment for inflammatory lung disease in the pulmonology department of the Ivano-Frankivsk Regional Phthisiopulmonology Center. In agreement with the attending physicians, they were sent to the sanatoriums "Diamond" and "Crystal" (Truskavets) where the main groups of 25 males and 6 females were created conditions for daily swimming for 18 days. The duration of each session was 45 minutes, and the amount of physical activity - 400-800 m at a heart rate of 120-140 b/m. Control groups were not used during their stay in the swimming sanatorium. A computer spirometer was used to assess the main 
indicators of external respiration function Microspiro HI-501. Determination of total physical performance was performed using a James test. The survey was performed twice (before and after the cycle of swimming). Results. A comparative analysis of changes in the mean values of tidal volume and vital capacity of the lungs of the control and main group of men shows that in the main group, these indicators of external respiration exceed the control group by $10.9 \%$ and $4.0 \%$, respectively $(p<0,05)$. The analysis shows that for women, the values of tidal volume and vital capacity of the lungs of the main group at the end of classes increased compared to the control group by $5.0 \%$ and $12.4 \%$, respectively. Probable changes were also found in both minute tidal volume, forced tidal volume, and peak expiratory rate in both men and women. Conclusion. The use of swimming in the recovery period of persons who have suffered from inflammatory diseases of the respiratory system provides normalization of the functioning of both respiratory and cardiovascular systems, which indirectly indicates the normalization of the mechanisms of neurohumoral regulation of body functions.

Keywords: swimming, inflammatory lung diseases, functional state.

Постановка проблеми й аналіз результатів останніх досліджень. В Україні хвороби органів дихання вже стали одними 3 найпоширеніших захворювань і становлять 26,5\% серед усіх вперше зареєстрованих недуг. В абсолютних цифрах це біля 7,8 млн осіб. Щодо Прикарпаття, то на даний час 0,4 млн людей страждають на запальні захворювання легень (З3Л), і ця патологія є четвертою за значимістю причиною смерті, а в структурі загальної інвалідності займає 21,5\% [1, 3, 8]. Серед основних причин, що сприяють розвитку цих патологічних станів виділяють такі: малорухливий спосіб життя, нераціональне харчування, хронічне стомлення, інтоксикація організму, алкоголізм, наявність осередків хронічної інфекції [6,7], а відтак зниження імунобіологічних властивостей організму.

Хвороби органів дихання характеризуються різноманіттям клініко-морфологічних проявів, що обумовлено великою кількістю етіологічних чинників, що призводять до розвитку недуг цих органів, віковими особливостями, структурно-функціональним станом легень $[2,10]$.

Не зважаючи на величезну кількість фармакологічних та нефармакологічних засобів лікування 33Л, не вдається істотно покращити та призупинити зниження функції зовнішнього дихання, уникнути персистенції системного запалення, загальмувати розвиток численних серйозних несприятливих генералізованих ефектів [4].

Відомо, що для удосконалення структурно-функціонального потенціалу органів дихання успішно використовуються найрізноманітніші засоби фізичної культури серед яких $є$ і плавання, яке визнано одним 3 найефективніших чинників щодо формування функціональних резервів апарату зовнішнього дихання $[4,5,8,9]$.

Мета дослідження - встановити вплив занять плаванням на відновлення функціональних резервів кардіореспіраторної системи після перенесених запальних захворювань легень.

Методи. У дослідженні взяли участь 50 осіб (12 жінок і 38 чоловіків, середній вік 42,01 $\pm 1,29$ років) після завершення стаціонарного лікування 3 приводу запальних захворювань легень в пульмонологічному відділенні Івано-Франківського обласного фтізіопульмонологічного центру. За погодженням з лікуючими лікарями вони були скеровані у санаторії “Алмаз" i "Кристал” (м. Трускавець) де основним групам (ОГ) у кількості 25 осіб чоловічої і 6 жіночої статі було створено умови для щоденних занять плаванням протягом 18 днів. Тривалість кожного заняття складала 45 хвилин, а обсяг фізичного навантаження - 400-800 м при ЧСС 120-140 уд/хв. Контрольні групи протягом перебування в санаторії плавання не використовували.

Для оцінки основних показників функції зовнішнього дихання використовувався комп'ютерний спірометр Microspiro HI-501. Визначення загальної фізичної працездатності здійснювали за допомогою проби Джеймса. Обстеження здійснювали двічі (до початку і після завершення циклу занять плаванням). 
Результати дослідження. Дані функціонального обстеження наведені в табл. 1. Як видно з даної таблиці, за період перебування в санаторіях як в контрольній, так і в основній групах відбулося вірогідне зменшення ЧСС в стані спокою. При цьому в основній групі величина цих змін, завдяки занять плаванням, досягла вірогідно суттєвіших змін, порівняно з групою контролю. Аналогічні зміни відбулися і щодо частоти дихання. Сукупність цих функціональних змін привела до покращення фізичної працездатності за показниками проби Джеймса (див. табл. 1).

Результати функціонального обстеження пацієнтів із 33Л

Таблиия 1 після впровадження реабілітаційної програми

\begin{tabular}{|l|c|c|c|}
\hline \multirow{2}{*}{ Показник } & До початку занять & \multicolumn{2}{|c|}{ Після завершення } \\
\cline { 3 - 4 } & плаванням & КГ, $\mathrm{n}=25$ & $\mathrm{O}, \mathrm{n}=25$ \\
\hline ЧСС, уд/хв & $85,1 \pm 0,5$ & $80,2 \pm 0,6^{*}$ & $78,3 \pm 0,4^{*}$ \\
\hline ЧД, д.р./хв & $29,1 \pm 0,9$ & $24,5 \pm 0,6^{*}$ & $21,7 \pm 0,4^{*}$ \\
\hline Проба Джеймса & $17,6 \pm 1,4$ & $19,6 \pm 1,15$ & $27,5 \pm 0,13^{*}$ \\
\hline
\end{tabular}

Примітка. $*-\mathrm{p}<0,05$.

У табл. 2 представлені результати спірографічного дослідження чоловіків. Порівняльний аналіз змін середніх значень дихального об'єму (ДО) і ЖЄЛ контрольної й основної групи свідчить про те, що в ОГ ці показники зовнішнього дихання перевищують дані КГ на 10,9\% і 4,0\% відповідно ( $<<0,05)$.

Таблиия 2

Показники функції зовнішнього дихання у чоловіків основної і контрольної груп до і після завершення перебування в санаторії

\begin{tabular}{|c|c|c|c|c|}
\hline \multirow[t]{2}{*}{ Показники } & \multicolumn{2}{|c|}{$\begin{array}{l}\text { Чоловіки ОГ } \\
(\mathrm{n}=19)\end{array}$} & \multicolumn{2}{|c|}{$\begin{array}{l}\text { Чоловіки КГ } \\
(\mathrm{n}=19)\end{array}$} \\
\hline & початок & кінець & початок & кінець \\
\hline ЖЄЛ, \% від належної & $56,88 \pm 1,43$ & $76,05 \pm 1,39 * \bullet$ & $58,15 \pm 1,68$ & $65,12 \pm 1,56^{*}$ \\
\hline $\begin{array}{l}\text { Об’єм форсованого видиху } 1, \\
\% \text { від належного }\end{array}$ & $55,80 \pm 1,81$ & $68,50 \pm 1,85 * \bullet$ & $54,36 \pm 1,76$ & $60,55 \pm 1,59$ \\
\hline $\begin{array}{l}\text { Пікова швидкість видиху, \% } \\
\text { від належної }\end{array}$ & $56,04 \pm 2,08$ & $65,28 \pm 1,73 * \bullet$ & $55,68 \pm 2,12$ & $58,89 \pm 1,93$ \\
\hline Дихальний обєм, л & $0,47 \pm 0,13$ & $0,53 \pm 0,12 * \bullet$ & $0,48 \pm 0,17$ & $0,49 \pm 0,14$ \\
\hline Хвилинний об’єм дихання, л & $11,03 \pm 0,72$ & $8,67 \pm 0,47 * \bullet$ & $10,96 \pm 0,60$ & $9,75 \pm 0,57$ \\
\hline
\end{tabular}

Примітки: достовірність різниці показників у порівнянні з такими до початку занять плаванням * $-\mathrm{p}<0,05$; достовірність різниці показників у порівнянні з такими у КГ: $\bullet-p<0,05$.

Особливості змін середніх значень показників зовнішнього дихання у жінок наведені в табл. 3. Аналіз засвідчує, що величини дихального об'єму та ЖЄЛ у осіб жіночої статі ОГ наприкінці занять зросли у порівнянні з групою контролю на 5,0\% і 12,4\% відповідно. Вірогідні зміни виявлені також і в показниках хвилинного об’єму дихання (див. табл. 3). 
Показники функції зовнішнього дихання у хворих на З3Л жінок обох груп на початку i наприкінці дослідження

\begin{tabular}{|l|c|c|c|c|}
\hline \multicolumn{1}{|c|}{ Показники ФЗД } & \multicolumn{2}{|c|}{$\begin{array}{c}\text { Жінки ОГ } \\
(\mathrm{n}=6)\end{array}$} & \multicolumn{2}{c|}{$\begin{array}{c}\text { Жінки КГ } \\
(\mathrm{n}=6)\end{array}$} \\
\cline { 2 - 5 } & початок & кінець & початок & кінець \\
\hline ЖЄЛ (\% від належної) & $55,35 \pm 2,19$ & $75,33 \pm 1,02^{*} \bullet$ & $56,40 \pm 1,97$ & $62,93 \pm 0,71^{*}$ \\
\hline $\begin{array}{l}\text { Об'єм форсованого ви- } \\
\text { диху 1,\% від належ- } \\
\text { ного }\end{array}$ & $52,98 \pm 2,06$ & $65,39 \pm 1,09^{*} \bullet$ & $52,14 \pm 1,84$ & $57,10 \pm 0,67^{*}$ \\
\hline $\begin{array}{l}\text { Пікова швидкість ви- } \\
\text { диху,\% від належної }\end{array}$ & $51,22 \pm 2,31$ & $60,07 \pm 1,21^{*} \bullet$ & $52,23 \pm 1,94$ & $54,62 \pm 1,82$ \\
\hline Дихальний обєм, л & $0,47 \pm 0,14$ & $0,52 \pm 0,14^{*} \bullet$ & $0,46 \pm 0,14$ & $0,47 \pm 0,14$ \\
\hline $\begin{array}{l}\text { Хвилинний об’єм ди- } \\
\text { хання, л }\end{array}$ & $11,05 \pm 0,81$ & $8,97 \pm 0,55^{*} \bullet$ & $11,15 \pm 0,72$ & $10,09 \pm 0,45$ \\
\hline
\end{tabular}

Примітка: достовірність різниці показників у порівнянні 3 такими до програми: $*-\mathrm{p}<0,05$; достовірність різниці показників у порівнянні з такими у КГ: $\bullet-\mathrm{p}<0,05$

Дискусія. У сучасних умовах в Україні склалася критична ситуація, пов'язана із значною кількістю запалень легень, які є наслідком багатьх чинників, але водночас й впливу на організм вірусу Covid-19. Як бачимо, одне тільки медикаментозне лікування не приносить бажаного ефекту і тому є стійка потреба застосування немедикаментозного впливу, особливо засобів фізичної культури [6]. Як засвідчують результати нашого дослідження, використання плавання забезпечує швидке відновлення структурнофункціонального потенціалу легень після запальних процесів в дихальній системі. Як зазначає В.І. Ляшенко та співавт. [4] - вода при певній температурі сприяє розслабленню м'язів і відновленню взаємодії їх при згинанні та розгинанні кінцівок, створює умови розвантаження хребта і фізіологічні передумови для динамічних рухів грудної клітки під час дихання. У воді покращується координація рухів, збільшується сила м'язів спини, грудної клітки та черевного пресу, формується правильне дихання і покращується функція серцево-судинної системи. Плавання створює умови для відновлення функціонального стану цілого організму [8]. В той же час засоби плавання, маючи надзвичайно широкий механізм дії та відновний ефект до останнього часу використовуються в основному тільки для відновлення уражень опорно-рухової системи 3 вираженими функціональними порушеннями та міофасціальним больовим синдромом [7].

Висновок. Застосування плавання у відновному періоді осіб, які перенесли запальні захворювання дихальної системи забезпечує нормалізацію функціонування як дихальної, так і серцево-судинної системи, що опосередковано свідчить про нормалізацію механізмів нейрогуморальної регуляції функцій організму.

1. Андрющенко ЛБ, Витько СЮ, Шутова ТН. Физкультурнооздоровительные технологии в укреплении состояния здоровья студентов и сотрудников вуза. Современные проблемы науки и образования. 2016; 5: 261-261.

2. Зайцев АА. Внебольничная пневмония: эпидемиология, диагностика и антимикробная терапія. Терапия. 2018; 1(19): 63-71.

3. Круглякова ЛВ, Нарышкина СВ. Тяжелая внебольничная пневмония: диагностика и лечение (обзор литературы). Бюл. физиологии и патологи дыхания. 2016; 59: 98-108.

4. Курко ЯВ. Плавання-засіб фізичної реабілітації у чутливих до зміни погоди людей. Педагогіка, психологія та медико-біологічні проблеми 216 фізичного виховання і спорту. 2011; 12: 54-57

5. Ляшенко АМ., Дєлова IО. До питання про методику навчання плаванню.Teoriâ ta Metodika Fìzičnogo Vihovannâ. 2014; 3: 33-35. 
Сарапук Роман. Ефективність застосування плавання для відновлення функціонального стану ...

6. Михеенко ОИ. Комплексная методика оценки уровня здоровья организма человека. Педагогика, психология и медико-биологические проблемы физического воспитания и спорта. 2011; 6: 93-101.

7. Надеев АП, Козяев МА, Абышев АА, Чеканов МН, Благитко ЕМ, Пешкова ИВ, Овсянко ЕВ. Внебольничная пневмония: эпидемиология, этиология и клинико-морфологические параллели. Journal of Siberian Medical Sciences. 2019; 4: 20-29.

8. Ньюсом П, Янг А. Эффективное плавание. Методика тренировки пловцов и триатлетов / пер. с анг. Дианы Айше ; под. ред. Сергея Ленивкина. М.: Манн, Иванов и Фербер, 2013; 400 с.

9. Філатова 3І. Особливості складання диференційованих програм 3 навчання плавання студентів спеціальної медичної групи. Науковий часопис НПУ імені МП Драгоманова. Серія 15: Науковопедагогічні проблеми фізичної культури (фізична культура і спорт). 2015; 3(1): 370-373.

10. Яців ЯМ., Лапковський ЕЙ. Оцінка фізичної підготовленості та функціонального стану осіб, що ведуть малорухомий спосіб життя. Вісник Прикарпатського університету. Серія: Фізична культура. 2014; 22: 81-86.

\section{References}

1. Andriushchenko LB, Vytko SIu, Shutova TN. Fyzkulturnoozdorovytelnыe tekhnolohyy v ukreplenyy sostoianyia zdorovia studentov y sotrudnykov vuza. Sovremennыe problemы nauky y obrazovanyia. 2016; 5: 261-261.

2. Zaitsev AA. Vnebolnychnaia pnevmonyia: эpydemyolohyia, dyahnostyka y antymykrobnaia terapiia. Terapyia. 2018; 1(19): 63-71.

3. Kruhliakova LV, Narbshkyna SV. Tiazhelaia vnebolnychnaia pnevmonyia: dyahnostyka y lechenye (obzor lyteraturы). Biul. fyzyolohyy y patolohy dыkhanyia. 2016; 59: 98-108.

4. Kurko YaV. Plavannia-zasib fizychnoi reabilitatsii u chutlyvykh do zminy pohody liudei. Pedahohika, psykholohiia ta medyko-biolohichni problemy 216 fizychnoho vykhovannia i sportu. 2011; 12: 54-57

5. Liashenko AM., Dielova IO. Do pytannia pro metodyku navchannia plavanniu.Teoriâ ta Metodika Fìzičnogo Vihovannâ. 2014; 3: 33-35.

6. Mykheenko OY. Kompleksnaia metodyka otsenky urovnia zdorovia orhanyzma cheloveka. Pedahohyka, psykholohyia y medyko-byolohycheskye problemы fyzycheskoho vospytanyia y sporta. 2011; 6: 93-101.

7. Nadeev AP, Koziaev MA, Abыshev AA, Chekanov MN, Blahytko EM, Peshkova YV, Ovsianko EV. Vnebolnychnaia pnevmonyia: эpydemyolohyia, эtyolohyia y klynyko-morfolohycheskye parallely. Journal of Siberian Medical Sciences. 2019; 4: 20-29.

8. Niusom P, Yanh A. Эffektyvnoe plavanye. Metodyka trenyrovky plovtsov y tryatletov / per. s anh. Dyanы Aishe ; pod. red. Serheia Lenyvkyna. M.: Mann, Yvanov y Ferber, 2013; 400 s.

9. Filatova ZI. Osoblyvosti skladannia dyferentsiiovanykh prohram z navchannia plavannia studentiv spetsialnoi medychnoi hrupy. Naukovyi chasopys NPU imeni MP Drahomanova. Seriia 15: Naukovopedahohichni problemy fizychnoi kultury (fizychna kultura i sport). 2015; 3(1): 370-373.

10. Iatsiv YaM., Lapkovskyi EI. Otsinka fizychnoi pidhotovlenosti ta funktsionalnoho stanu osib, shcho vedut malorukhomyi sposib zhyttia. Visnyk Prykarpatskoho universytetu. Seriia: Fizychna kultura. $2014 ; 22: 81-86$.

\begin{tabular}{|c|c|}
\hline \multicolumn{2}{|l|}{ Цитування на цю статтю: } \\
\hline \multicolumn{2}{|c|}{$\begin{array}{l}\text { Роман Сарапук Ефективність застосування плавання для відновлення функціонального стану } \\
\text { кардіореспіраторної системи після перенесених запалень легень. Вісник Прикарпатського університету. } \\
\text { Серія: Фізична культура. } 2020 \text { Листоп 24; 36: 53-57 }\end{array}$} \\
\hline Відомості про автора: & Information about the author: \\
\hline $\begin{array}{l}\text { Сарапук Роман Ігорович- Тернопільський націо- } \\
\text { нальний медичний університет імені І.Я. Гор- } \\
\text { бачевського (Тернопіль, Україна) }\end{array}$ & $\begin{array}{l}\text { Sarapuk Roman Ihorovych - I. Horbachevsky Ter- } \\
\text { nopil National Medical University (Ternopil, Ukraine) }\end{array}$ \\
\hline e-mail: rivo@tvnet.if.ua & \\
\hline
\end{tabular}

